\title{
ROLE OF ANTIBIOTIC IN BRONCHIOLITIS MANAGEMENT
}

\author{
Akhtar $\mathrm{K}^{1}$, Chowdhury $\mathrm{RB}^{2}$, Rahman $\mathrm{MT}^{3}$
}

\begin{abstract}
Introduction: Bronchiolitis is the most common illness among the patients attending the outpatient departments of $\mathrm{CMH}$. It is predominantly a viral disease affecting the infants and young children. Though Antibiotic has little role, pediatricians frequently use them during bronchiolitis management. Very few randomized control trials without antibiotics in the management of bronchiolitis have so far been done.
\end{abstract}

Objectives: To evaluate the outcome of bronchiolitis with or without antibiotics in a hospital setting.

Methods: This prospective randomized control study was done in $\mathrm{CMH}$ Savar, during six months from October 2012 to March 2013. All the children below two years admitted in $\mathrm{CMH}$ Savar with first attack of Clinical Bronchiolitis were our study population. Exclusion criteria were: (i) atopic condition, (ii) congenital heart disease and/or (iii) known immunodeficiency. Study cases were randomly assigned into one of the two groups, $A B$ group (Erythromycin/Amoxycilin) and NAB group (No Antibiotic).The NAB group was considered as control group. Supportive treatment was given according to the national guideline for management of bronchiolitis. Presenting symptoms and signs were followed-up twice daily while hospitalized and 7 days after discharge to determine the progress of disease.
Outcome was determined by the progress of the variables in the structured follow-up format. Permission of commanding officer $\mathrm{CMH}$ Savar and verbal consent of the parents were taken before the study.

Results: Fifty-four cases who could be followed up till after seven days of discharge were finally included in the study. Among them about half $(25 / 54)$ received oral or intravenous antibiotic while rest (29/54) received only supportive therapy but no antibiotic (NAB group). Most of the cases were below six months of age. Male were about double of the female (37:17). The presenting features were cough, wheeze, fever and feeding difficulty. Clinical features of both groups progressed similarly in both the groups. With the given treatment 24 (96\%) cases from $A B$ group and 27 (93\%) cases from $N A B$ group improved and were discharged safely. 01 from $A B$ and 02 from $N A B$ group deteriorated and were then treated with broad spectrum antibiotics. There was no death. Mean hospital stay of $A B$ group (5.6 days) was little longer than NAB group (4.2 days) and $16 \%$ (4/25) of them had respiratory symptoms at seven days follow up, but the difference of outcome between the two groups was not statistically significant.

Conclusion: Antibiotics have no role in acute bronchiolitis management.

1. Lt Col Khaleda Akhtar, MBBS, DCH, FCPS, Graded Specialist in Child Health, Savar CMH, Savar Cantonment, Dhaka; 2. Brig Gen Rehana Begum Chowdhury, MBBS, DCH, FCPS, Adviser Specialist in Child Health, Armed forces Medical College, Dhaka Cantonment, Dhaka; 3. Dr. Md. Tauhidur Rahman, MBBS, DO, MS (Eye), MMEd, Associated Professor (Eye), DG health, Mohakhali, Dhaka. 
Key-Words: Wheeze, Bronchiolitis, Antibiotic, Outcome.

\section{Introduction}

Bronchiolitis is the most common acute lower respiratory tract infection in infants and young children and represents a common reason for attendance in the emergency and casualty department and for hospital admission. It is predominantly a viral disease and is characterized by acute inflammation, edema and necrosis of epithelial cells lining small airways, increased mucus production and bronchospasm ${ }^{2}$. Respiratory syncytial virus (RSV) accounts for $40 \%$ of bronchiolitis, other viruses are influenza, adenovirus and parainfluenza ${ }^{3}$. The incidence peaks during winter and early spring and reaches near zero in late summer and autumn. In the majority of infants with bronchiolitis, the illness is mild but nearly $4-5 \%$ requires hospitalization among which respiratory failure develops in 5-7\% cases and $1 \%$ dies ${ }^{4}$. In the United States nearly 150,000 infants are hospitalized each year with bronchiolitis ${ }^{5}$. Presentation of the disease is paroxysmal wheezy cough, dyspnoea, irritability and respiratory distress following a mild upper respiratory tract infection with sneezing and clear rhinorrhea. The most prominent physical examination is wheezing. Other findings are tachypnoea, chest retraction, crepitation and rhonchi ${ }^{6}$. The natural history of bronchiolitis is of a self-limiting disease that lasts 3-7 days and management is thus primarily supportive. Indications for hospitalization include poor feeding, lethargy, history of apnoea, respiratory rate $>70 /$ min, presence of nasal flaring and/or grunting, severe chest wall recession or oxygen saturation less than $95 \%{ }^{7}$. Supportive care in the form of assisted feeding, gentle nasal suctioning and oxygen therapy are the mainstay of treatment for the majority of infants. Other treatments include bronchodilator, ribavarine and corticosteroids ${ }^{8}$. Several studies have shown a wide variation in the treatment of bronchiolitis in United States, Canada and Netherlands ${ }^{9}$. This variable pattern suggests a lack of consensus among the clinicians as to best practice. In the last epidemic (2002) of Bangladesh
$50 \%$ cases were positive for RSV antibody and those antibodies were used in almost all cases ${ }^{10}$. Kupperman showed in a prospective study that none of 156 patients with bronchiolitis had bacteremia ${ }^{11}$. Levine concluded that antibiotic may only be necessary when bacterial pneumonia is suspected e.g. high fever, toxicity, leukocytosis and lober infiltrate $^{12}$. It has been shown repeatedly that inappropriate use of antibiotic promotes the development of resistant organisms ${ }^{13}$. But very few studies have been done on this topic in developing countries. This study was conducted to find out the role of antibiotic in addition to supportive therapy in the management of bronchiolitis.

\section{Materials \& Methods}

This was a prospective randomized control study done in $\mathrm{CMH}$ Savar, during six months from October 2012 to March 2013. All the children below two years admitted in CMH Savar with bronchiolitis were our study population. Inclusion criteria were: (i) age up to two years, (ii) first attack of wheeze, (iii) not treated previously. The cases having: (i) atopic condition, (ii) congenital heart disease and/or (iii) known immunodeficiency were excluded from the study.

Sample size was estimated at eighty for the study. Forty cards in each group were marked as NAB (No Antibiotic) and $A B$ (Antibiotic: Oral Erythromycin/ Parenteral Amoxycilin) respectively. Each card was kept in a sealed envelope and repeated shuffling of total cards was done with a serial number put on each envelope. As per their admission serial the study cases were assigned, enveloped and the investigator was totally unaware of the treatment modalities before opening it. The NAB group was considered as control group.

Structured questionnaire were filled up after taking a detailed history and thorough examination of the child was done by the investigator. Initial investigations such as complete blood picture $(\mathrm{CBC})$, C-reactive protein (CRP), oxygen saturation $\left(\mathrm{SpO}_{2}\right)$ and $\mathrm{X}$-ray chest P/A view were done for all the patients. 
Supportive treatment was given according to the national guideline for management of bronchiolitis. Oxygen $\left(\mathrm{SpO}_{2}<95 \%\right)$ and nebulization were given instantly at admission and 6-8 hourly and after that according to the clinical condition. The cases were followed up twice (morning and evening) daily. Structured follow-up format included cough, wheeze (noisy respiration), fever, feeding difficulty, tachypnea, chest indrawing, hypoxia, rhonchi and crepitation. During hospital stay, the child was withdrawn from the study only when the child's condition deteriorated further. The patients were discharged from hospital when they had adequate feeding, no respiratory distress and no requirement for $\mathrm{O}_{2}$ therapy. The patients were followed up 3 days and 7 days after discharge from the hospital. Outcome was determined by the progress of the variables in the structured follow-up format. The study was done with permission of commanding officer $\mathrm{CMH}$ Savar. Verbal consent of the parents was taken before enrolling in the study. All data were recorded and checked by the investigator and analyzed in the computer using statistical software.

\section{Results}

After 10th March 2013, bronchiolitis was not reported, so the study ended with enrollment of 67 cases. Among them 54 children who could be followed up till after seven days of discharge were finally included in the study. Rest were lost during follow up. Most of the cases were below six months of age. Male were about double of the female (37:17). The presenting features were cough, wheeze (Noisy respiration), fever and feeding difficulty. At admission all of them had rhonchi (100\%). Most of them had tachypnea (93\%) and chest indrawing $(80 \%)$. Sixty one percent of them had hypoxia $\left(\mathrm{SpO}_{2}<95 \%\right)$ and $48 \%$ had crepitation. Complete blood picture was done in all the cases, mean TWBC count was $8900 / \mathrm{cmm}$. The mean neutrophil and lymphocyte count were $35 \%$ and $61 \%$ respectively. CRP was found $<6$ in $80 \%$ cases, $<12$ in $13 \%$ cases and $<24$ in $07 \%$ cases. X-ray chest P/A view in all cases had similar features suggestive of bronchiolitis ${ }^{1}$ hyperinflation was found in $61 \%$ cases, hypertranslucency in $44 \%$ cases and streaky densities in $31 \%$ cases. Palpable liver was found in $41 \%$ cases. Among these 54 cases about half $(25 / 54)$ received oral or intravenous antibiotic while rest (29/54) did not receive antibiotics. The clinical parameters at admission, course during hospital stay and outcome of the two groups were compared (Figure-1, Table-I \& Table-II).

\section{Total 67 children were enrolled in the study}

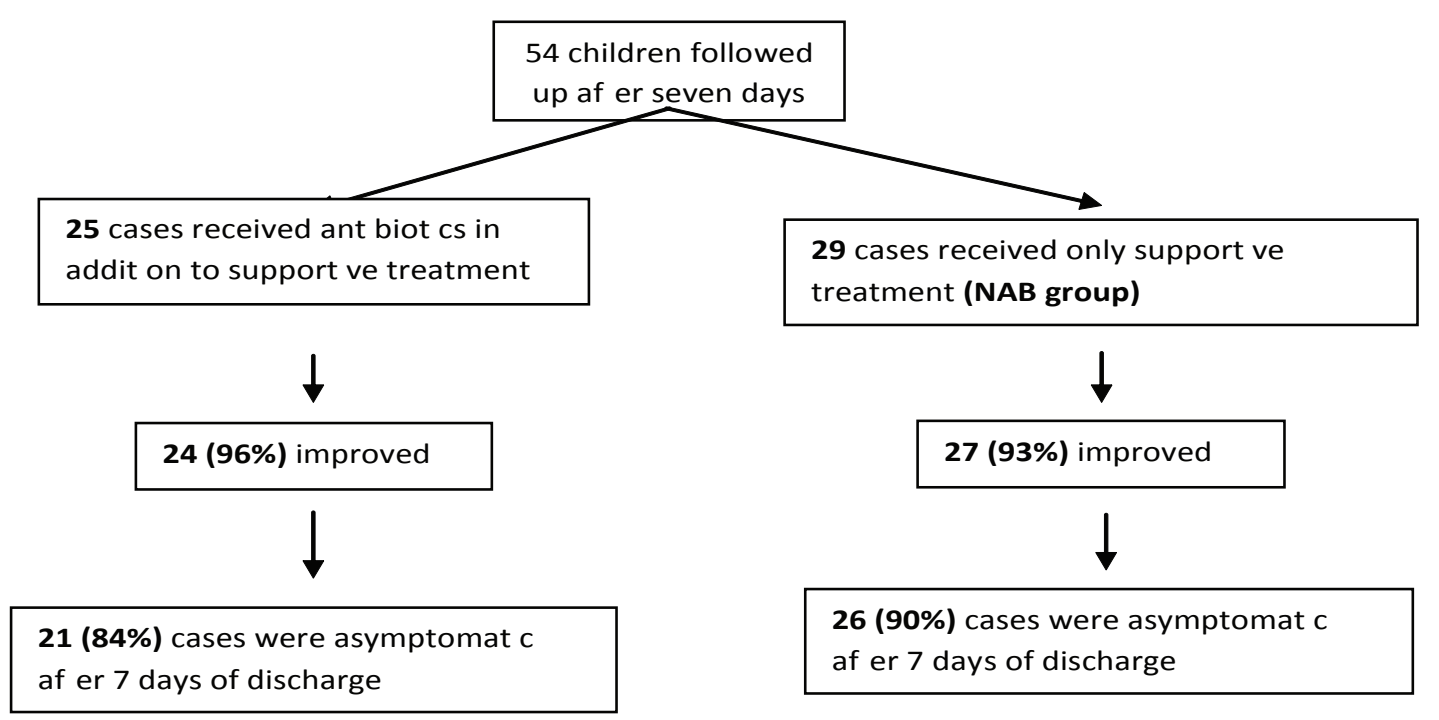

Fig-1: Study diagram. 
Table-I: Progress of symptoms and signs after 48 hours of treatment and 7 days after discharge. (Total number $\mathrm{N}=54$ )

\begin{tabular}{|c|c|c|c|c|c|c|c|c|c|}
\hline $\begin{array}{l}\text { Sl. } \\
\text { No }\end{array}$ & Parameter & Antib & $\begin{array}{l}\text { tic }(A B \text { c } \\
n=25(\%)\end{array}$ & roup) & N0 Antil & $\begin{array}{l}\text { otic (NA } \\
n=29(\%)\end{array}$ & group) & & \\
\hline & Clinical Features & $\begin{array}{c}\text { At } \\
\text { admission }\end{array}$ & $\begin{array}{l}48 \text { hours } \\
\text { after } \\
\text { admission }\end{array}$ & $\begin{array}{c}7 \text { days } \\
\text { after } \\
\text { discharge }\end{array}$ & $\begin{array}{c}\text { At } \\
\text { admission }\end{array}$ & $\begin{array}{l}48 \text { hours } \\
\text { after } \\
\text { admission }\end{array}$ & $\begin{array}{c}7 \text { days } \\
\text { after } \\
\text { discharge }\end{array}$ & $\begin{array}{l}48 \text { hours } \\
\text { after } \\
\text { admission }\end{array}$ & $\begin{array}{c}7 \text { days } \\
\text { after } \\
\text { discharge }\end{array}$ \\
\hline 01 & Cough $36(67 \%)$ & $\begin{array}{c}16 \\
(64 \%)\end{array}$ & $\begin{array}{c}08 \\
(50 \%)\end{array}$ & $\begin{array}{c}04 \\
(25 \%)\end{array}$ & $\begin{array}{c}20 \\
(69 \%)\end{array}$ & $\begin{array}{c}09 \\
(45 \%)\end{array}$ & $\begin{array}{c}03 \\
(15 \%)\end{array}$ & $>0.5$ & $>0.4$ \\
\hline 02 & $\begin{array}{c}\text { Wheeze (Noisy } \\
\text { Respiration) 32(59\%) }\end{array}$ & $\begin{array}{c}15 \\
(60 \%)\end{array}$ & $\begin{array}{c}08 \\
(53 \%)\end{array}$ & $\begin{array}{c}02 \\
(13 \%)\end{array}$ & $\begin{array}{c}17 \\
(59 \%)\end{array}$ & $\begin{array}{c}08 \\
(47 \%)\end{array}$ & $\begin{array}{c}03 \\
(18 \%)\end{array}$ & $>0.5$ & $>0.5$ \\
\hline 03 & Fever $25(46 \%)$ & $\begin{array}{c}12 \\
(48 \%)\end{array}$ & $\begin{array}{c}02 \\
(17 \%)\end{array}$ & $\begin{array}{c}00 \\
(00 \%)\end{array}$ & $\begin{array}{c}13 \\
(45 \%)\end{array}$ & $\begin{array}{c}03 \\
(23 \%)\end{array}$ & $\begin{array}{c}00 \\
(00 \%)\end{array}$ & $>0.5$ & --- \\
\hline 04 & $\begin{array}{l}\text { Feeding Difficulty } \\
23(43 \%)\end{array}$ & $\begin{array}{c}11 \\
(44 \%)\end{array}$ & $\begin{array}{c}03 \\
(27 \%)\end{array}$ & $\begin{array}{c}00 \\
(00 \%)\end{array}$ & $\begin{array}{c}12 \\
(41 \%)\end{array}$ & $\begin{array}{c}03 \\
(25 \%)\end{array}$ & $\begin{array}{c}00 \\
(00 \%)\end{array}$ & $>0.5$ & --- \\
\hline 05 & Tachypnea 50(93\%) & $\begin{array}{c}23 \\
(92 \%)\end{array}$ & $\begin{array}{c}08 \\
(35 \%)\end{array}$ & $\begin{array}{c}02 \\
(09 \%)\end{array}$ & $\begin{array}{c}27 \\
(93 \%)\end{array}$ & $\begin{array}{c}09 \\
(33 \%)\end{array}$ & $\begin{array}{c}02 \\
(07 \%)\end{array}$ & $>0.5$ & $>0.5$ \\
\hline 06 & $\begin{array}{c}\text { Chest Indrawing } \\
45(83 \%)\end{array}$ & $\begin{array}{c}20 \\
(80 \%)\end{array}$ & $\begin{array}{c}07 \\
(35 \%)\end{array}$ & $\begin{array}{c}01 \\
(05 \%)\end{array}$ & $\begin{array}{c}25 \\
(86 \%)\end{array}$ & $\begin{array}{c}08 \\
(32 \%)\end{array}$ & $\begin{array}{c}00 \\
(00 \%)\end{array}$ & $>0.5$ & $>0.5$ \\
\hline 07 & $\begin{array}{c}\text { Hypoxia }\left(\mathrm{O}_{2} \text { saturation }\right. \\
<95 \%) 33(61 \%)\end{array}$ & $\begin{array}{c}17 \\
(68 \%)\end{array}$ & $\begin{array}{c}06 \\
(35 \%)\end{array}$ & $\begin{array}{c}00 \\
(00 \%)\end{array}$ & $\begin{array}{c}16 \\
(55 \%)\end{array}$ & $\begin{array}{c}05 \\
(31 \%)\end{array}$ & $\begin{array}{c}00 \\
(00 \%)\end{array}$ & $>0.5$ & $\begin{array}{ll}-- \\
\end{array}$ \\
\hline 08 & Rhonchi 54(100\%) & $\begin{array}{c}25 \\
(100 \%)\end{array}$ & $\begin{array}{c}09 \\
(36 \%)\end{array}$ & $\begin{array}{c}02 \\
(08 \%)\end{array}$ & $\begin{array}{c}29 \\
(100 \%)\end{array}$ & $\begin{array}{c}10 \\
(34 \%)\end{array}$ & $\begin{array}{c}03 \\
(10 \%)\end{array}$ & $>0.5$ & $>0.5$ \\
\hline 09 & Crepitation 26(48\%) & $\begin{array}{c}11 \\
(44 \%)\end{array}$ & $\begin{array}{c}04 \\
(36 \%)\end{array}$ & $\begin{array}{c}02 \\
(18 \%)\end{array}$ & $\begin{array}{c}15 \\
(52 \%)\end{array}$ & $\begin{array}{c}05 \\
(33 \%)\end{array}$ & $\begin{array}{c}01 \\
(07 \%)\end{array}$ & $>0.5$ & $>0.4$ \\
\hline
\end{tabular}

Table-II: Outcome of bronchiolitis with different modalities of treatment (along with comparison)

\begin{tabular}{|l|l|l|l|}
\hline Outcome & AB group (n=25) & NAB group (n=29) & P \\
\hline Improved & $24(96 \%)$ & $27(93 \%)$ & $\mathrm{p}>0.5$ \\
\hline Deteriorated & $1(04 \%)$ & $2(07 \%)$ & $\mathrm{p}>0.5$ \\
\hline Mean Hospital stay & $5.6 \pm 3.2$ (days) & $4.2 \pm 1.8$ (days) & $\mathrm{p}>0.05$ \\
\hline $\begin{array}{l}\text { Asymptomatic at } \\
\text { follow up (7 days after } \\
\text { discharge) }\end{array}$ & $21(84 \%)$ & $26(90 \%)$ & $\mathrm{P}>0.5$ \\
\hline
\end{tabular}


Clinical parameters resolved earlier in NAB Group compared to antibiotic group though the difference was not statistically significant. Almost all patients improved with the treatment except three, two from $N A B$ group and one from $A B$ group needed intervention. They were treated by broad spectrum antibiotic and one of them received steroid. No patient expired during treatment. Mean hospital stay was little longer in AB group (5.6 days) compared to NAB group (4.2 days) and 16\% $(4 / 25)$ of them had respiratory symptoms at seven days follow up, but the difference of outcome between the two groups was not statistically significant.

\section{Discussion}

This randomized control trial provided us the opportunity to see the outcome of bronchiolitis with or without antibiotic in a hospital setting. We strictly followed the case definition of clinical bronchiolitis $^{1,14,15}$. All children were between one month to 2 years old with preceding/existing runny nose, cough, breathing difficulty, lower chest indrawing, wheeze and rhonchi on auscultation. Hematological profile was similar to other studies $^{16,17}$ in both groups, mean TWBC count was 8900/cmm.

Mean neutrophil and lymphocyte count were 35\% and $61 \%$ respectively. CRP was found $<6$ in $80 \%$ cases, $<12$ in $13 \%$ cases and $<24$ in $07 \%$ cases. Radiological features of all cases had similar features suggestive of bronchiolitis ${ }^{1}$. Hyperinflation was found in $61 \%$ cases, hypertranslucency in $44 \%$ cases and streaky densities in $31 \%$ cases. In $41 \%$ cases palpable liver was found probably because downward displacement of the organ by hyperinflation of the lung. In this study cases were randomized by lottery (repeated shuffling of the cards in sealed envelope). At follow up at 1 week after discharge number of the patients in $A B$ group was 25(n1), and in NAB group 29(n2) (Total $N=$ 54). Most of the cases were below six months of age as seen in Europe, Australia and North America $^{18}$. In the study male children were about double of the female $(37: 17)$ which is in conformity with observation all over the world ${ }^{10,11,12}$.
Cough (67\%) and noisy respiration (59\%) were the most common presenting features in our study. They persisted for a longer period and improved slowly. It was more delayed in $A B$ group but the difference was very little and was not significant $(p>0.5)$. Similar finding was stated by others ${ }^{19,20}$. About $46 \%$ children presented with fever and all of them recovered from fever quickly before leaving hospital $(p>0.5)$. Similar finding was noticed by Radhi et $\mathrm{al}^{21}$. Another presenting feature was feeding difficulty. Feeding difficulty is considered as a factor of severe disease by Mulholand and nasogastric feeding is suggested until recovery ${ }^{22}$. At the time of admission $43 \%$ children had feeding difficulty, which improved steadily and similarly in both the groups $(p>0.5)$.

Most of the children had tachypnea (93\%) and chest indrawing $(80 \%)$ at the time of admission. Tachypnea improved gradually. At forty eight hours after admission about one-third of the total children had tachypnea, in $A B$ group $35 \%$ and in NAB group $33 \%(p>0.5)$. During follow up at 7 days after discharge $09 \%$ of $A B$ group and $07 \%$ of NAB group still had tachypnea $(p>0.5)$. Forty eight hours after admission $35 \%$ of $A B$ group and $32 \%$ of $N A B$ group had similar chest indrawing ( $p>0.5)$.

Pulse oxymetry is being used since 1980 and is now widely regarded as fifth vital $\operatorname{sign}^{23}$. American Academy of Pediatrics considers maintaining higher $\mathrm{SpO}_{2}$ in children with risk factors like fever, acidosis or severe anaemia ${ }^{2}$. Adverse cognition and behavioral outcome at $\mathrm{SpO}_{2}$ level $90-94 \%$ supports the use of $\mathrm{O}_{2}$ in the present study in case of $\mathrm{SpO}_{2}$ $<95 \%{ }^{1}$. None of the cases showed cyanosis and at the time of admission total $61 \%$ children had $\mathrm{SpO}_{2}$ $<95 \%$, after 48 hours of admission $35 \%$ of $A B$ group and $31 \%$ of NAB group still had $\mathrm{SpO} 2<95 \%$ but during discharge none of them had hypoxia. The difference between the two groups was not statistically significant. This finding matches with other's findings ${ }^{19,20,24}$. On the day of admission $100 \%$ children had rhonchi, after 48 hours, about one-third of the total children had rhonchi; $36 \%$ of $A B$ group and $N A B, 34 \%$ of group ( $p>0.5$ ). 
During follow up on 7 days after discharge $7 \%$ of $A B$ group and $10 \%$ of $N A B$ group still had rhonchi $(p>0.5)$. The difference between the two groups was not statistically significant as shown by others $^{19,20}$. Less than half $(48 \%)$ of the cases had crepitation on the day of admission, $44 \%$ of the $A B$ group and $52 \%$ of $N A B$ group. After 48 hours of admission $36 \%$ of $A B$ group and $33 \%$ of $N A B$ group had crepitation and 7 days after discharge $1(7 \%)$ child of $N A B$ group and $2(18 \%)$ from $A B$ group still had crepitation, but the difference was not statistically significant. High incidence rate, admission rate and relatively ineffective therapies make the treatment of bronchiolitis controversial. Current management protocol is supportive $-\mathrm{O}_{2}$ therapy, nasal clearance, hydration therapy and bronchodilators $^{9,25}$. Antibiotic has been advocated in children with bronchiolitis who have specific indications of coexisting bacterial infection ${ }^{26}$. There was no fatality in this study as shown in other studies $^{9,19,25}$. Deterioration in $A B$ group was less but hospital stay was longer and statistically there was no significant difference when compared with NAB group. Few randomized control studies conducted so far on use of antibiotic in bronchiolitis, also found no evidence to support the use of antibiotics for bronchiolitis ${ }^{19,20,27,28}$.

\section{Conclusion}

Supportive therapy alone is highly effective for clinical improvement of bronchiolitis and a significant proportion of first time wheezers can be managed without antibiotics. Limitation of the study was shortfall of sample size.To support the findings of the study further multicenter study with larger sample size is recommened.

\section{References}

1. Duiverman EJ, Neijen HJ, Van Strik R, Affoutit MJ, Kerrebijin KF. Lung function and bronchial responsiveness in children who had infantile bronchiolitis. Pediatr Pulmonol 1987; 3:38-46.
2. American Academy of pediatrics- Subcommittee on diagnosis and management of bronchiolitis. Pediatrics 2006;118:1774-93.

3. Stein RT, Sherill D, Morgan WJ. Respiratory syncitial virus in early life and risk of wheeze and allergy by age 13 years. Lancet 1999;354:541-5.

4. Shay DK, Holman RC, Newman RD, Lice LL, Stout JW, Anderson LJ. Bronchiolitis associated mortality and estimates of respiratory syncitial virus associated death among US children 1979-97. J Infect Dis 2001;183:16-22.

5. Pelletier AJ, Mansbach JM, CamargoCAJ. Direct medical cost of bronchiolitis hospitalizations in the United States. Pediatrics 2006;118:2418-23.

6. Behrman RE, Kliegman RM, Jenson $H B$, Stanton BF. Nelson Textbook of Pediatrics 18th edition 2007; 1773-1777.

7. SIGN. Scottish Intercollegiate Guideline Network 91: Bronchiolitis in Children. www.sign.ac.uk/pdf/ sign91.pdf2006 (accessed on 15 December 2013).

8. Goh A, Chay OM, Foo AL, Ong EK. Efficacy of bronchodilators in the treatment of bronchiolitis. Singapore Med J 1997;38:326-8.

9. Rakshi K, Couriel JM. Management of Acute bronchiolitis. Arch Dis child 1994;71:463-9.

10. Majumder MJU, Hossain MM, Kabir ARML. Management of bronchiolitis with or without antibiolitic. Bangladesh J Child Health 2005;29:41-5.

11. Kupperman N, Bank DE, Walton EA, Senac $\mathrm{MO}$, McCaslin I. Risk of bacteremia and urinary tract infections in young febrile children with bronchiolitis. Arch Pediatric Adolesc Med 1997;151:1207-14. 
13. Spach DH, Black D. Antibiotic resistance in community acquired respiratory tract infection; Current Issues Ann Allergy Asthma Immunol 1998;81:293-302.

14. Fitzgerald DA, Kilham HA. Bronchiolitis: assessment and evidence-based management. Medical Journal of Australia 2004;180:399-404.

15. Wohl MEB, Chemic V. State of art: bronchiolitis. Am Rev Respir Dis 1978;118:59-81.

16. Kabir ARM, Haq N, Amin R, Hossain A, Khatoon S, Shahin A et al. Evaluation of hospitalized infants and young children with bronchiolitis - a multi center study. Mymenshing Med J 2003 Jul; 12(2):128-133.

17. Ackerman BD. Acute bronchiolitis. Clin Pediatr 1962;1:75-81.

18. Sharland $M$, Russel $A B$. Preventing respiratory syncytial virus bronchiolitis.BMJ 2001;322:62-3.

19. Rasul CH, Kabir A, Rashid AKMM, Hassan MA. Role of antibiotic in the outcome of bronchiolitis. Pak J Med Sci 2008;24(5):707-11.

20. Majumder MJU, Hossain MM, Kabir ARML. Management of bronchiolitis with or without antibiotic $-\mathrm{A}$ randomized control trial. J Bangladesh Coll Phys Surg 2009;27:63-9.//.
21. Radhi ASE, Barry W, Patel S. Association of fever and severe clinical coursr in bronchiolitis. Arch Dis Child 1999;81:231-4.

22. Mulholand EK, Olinsky A, Shamm FA. Clinical findings and severity of acute bronchiolitis. Lancet 1990;338:1259-61.

23. Mower WR, Sachs C, Nicklin EL, Baraff LJ. Pulse oxymetry as a fifth pediatric vital sign. Pediatrics 1997;101:681-6.

24. Corneli HM, Zorc JJ, Holubkov $\mathrm{R}$ et al. Bronchiolitis - Clinical characteristics associated with hospitalization and length of stay. Pediactr Emer Care 2012;28:99-103.

25. Flores G, Horwitz RI. Efficacy of agonists in bronchiolitis. Pediatrics 1997;100:233-9.

26. Titus MO, Wright SW. Prevalence of serious bacterial infection in febrile infants with respiratory syncitial virus infection. Pediatrics 2003;112:282-4.

27. Patra S, Singh V, Pemde HK, Chandra J. Antibiotic prescribing pattern in paediatric in patients with first time wheezing. Italian Journal of Peditrics 2011;37:40. www.ijponline.net/content/37/1/40. (accessed on 15 December 2013).

28. Spurling GK, Fonseka K, Doust J, Del Mar C. Antibiotics for bronchiolitis in children. Chochrane Database Syst Rev 2007;24(1):CD 1.005189. 